60. MRI検査における化粧品の影響

\title{
Effects of cosmetics on MRI
}

東京慈恵会医科大学柏病院

○平川英滋 飯高晃治 岸 孝幸

春原信雄 佐藤 清

Eiji Hirakawa Kohji Iidaka Takayuki Kishi

Nobuo Sunohara Kiyoshi Sato

[目的] MRI検查を行う場合、磁性体（ペースメーカー、体内金属、金属性装身具等）の 安全チェックは㛜重に行われているが、化粧品、特に磁性体顔料については、報告さ れていない。今回我々は、MRI検查における化粧品の安全性、影響について検討した ので報告する。

[使用機器］ MRP-20(垂直磁場 $0.2 \mathrm{~T}$ ) MRH-1500(水平磁場 $1.5 \mathrm{~T}$ )

[方法] 1.方眼紙に化粧品 $\left(1 \mathrm{mg} / \mathrm{cm}^{2}\right)$ を塗り、磁場強度および、パルスシーケンスによる 違いを検討する。

2.ボランテイアに化粧品を塗布し、人体に対する影響、安全性も検討する。 [結果及び考察] 1.パルスシーケンスによるアーチファクトに違いが見られたが、磁場強 度による違いは見られなかった。(Fig 1)

2.化粧品のなかでも特にマスカラやアイライナーは画像に影響を与える。これは、商 品中に含まれる磁性体の、黒酸化鉄の量が多い為と思われる。(Fig 2)

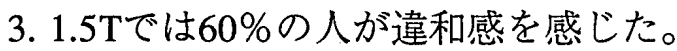

4.皮膚及び眼䆞部の検查には化粧品に対する注意が必要である。(Fig 3)

[まとめ] MRI検査を行う場合、体内金属の注意事項 検査前チェックは、徹底されている。しかし、 化粧品についての注意は、設置装置による違い はあるが、施設によって対応が様々である。そ して、化粧品による影響についての報告もあま りされていない。これから色々新しい化粧品が 開発されることと思われるが、化粧品によって は、注意が必要である。

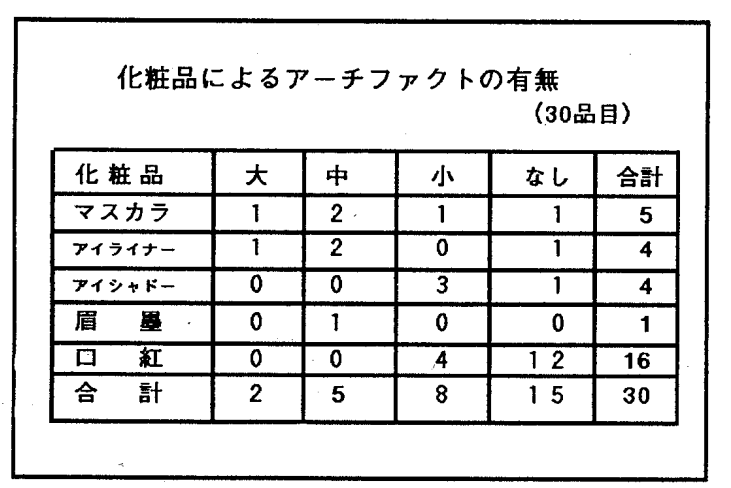

Fig 2

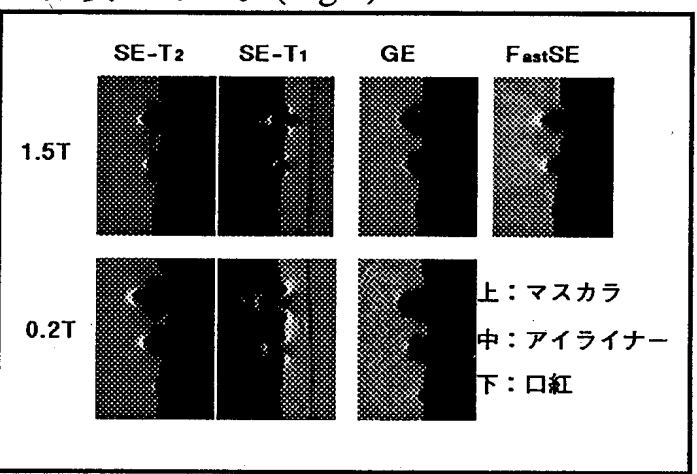

Fig 1

化粧品によるアーチファクト

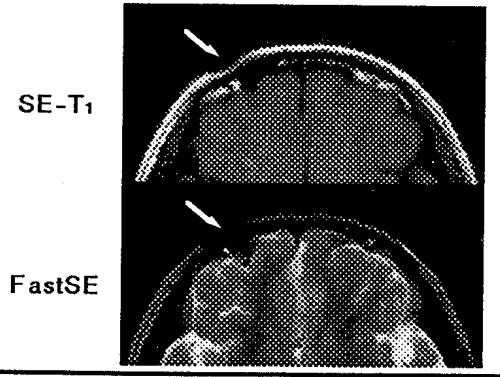

Fig 3 